\title{
Article \\ Heating/Cooling Fresh Air Using Hot/Cold Exhaust Air of Heating, Ventilating, and Air Conditioning Systems
}

\author{
Mahmoud Khaled ${ }^{1,2, *(\mathbb{D})}$, Samer Ali ${ }^{3} \mathbb{D}$, Hassan Jaber ${ }^{1}$, Jalal Faraj ${ }^{1,4}$, Rabih Murr ${ }^{5}$ and Thierry Lemenand ${ }^{6, *(D)}$ \\ 1 Energy and Thermofluid Group, The International University of Beirut BIU, Beirut P.O. Box 146404, Lebanon; \\ hassan.jaber@liu.edu.lb (H.J.); jalal.faraj@liu.edu.lb (J.F.) \\ 2 Sorbonne Paris Cite, Interdisciplinary Energy Research Institute (PIERI), University Paris Diderot, \\ 75205 Paris, France \\ 3 Smart Systems and Energies Department, Junia HEI, 59000 Lille, France; samer.ali@junia.com \\ 4 Faculty of Technology, Lebanese University, Saida P.O. Box 657314, Lebanon \\ 5 Energy and Thermofluid Group, Lebanese International University LIU, Bekaa P.O. Box 146404, Lebanon; \\ rabih.nurr@liu.edu.lb \\ 6 LARIS EA 7315, Polytech Angers, School of Engineering, University of Angers, 49000 Angers, France \\ * Correspondence: mahmoud.khaled@liu.edu.lb (M.K.); thierry.lemenand@univ-angers.fr (T.L.)
}

Citation: Khaled, M.; Ali, S.; Jaber, H. Faraj, J.; Murr, R.; Lemenand, T. Heating/Cooling Fresh Air Using Hot/Cold Exhaust Air of Heating, Ventilating, and Air Conditioning Systems. Energies 2022, 15, 1877. https://doi.org/10.3390/en15051877 Academic Editors: Ning Li, Jian Dai, Weirong Zhang and Ziwei Li

Received: 15 January 2022

Accepted: 1 March 2022

Published: 3 March 2022

Publisher's Note: MDPI stays neutral with regard to jurisdictional claims in published maps and institutional affiliations.

Copyright: (C) 2022 by the authors. Licensee MDPI, Basel, Switzerland. This article is an open access article distributed under the terms and conditions of the Creative Commons Attribution (CC BY) license (https:// creativecommons.org/licenses/by/ $4.0 /)$.

\begin{abstract}
This paper suggests a heat recovery concept that is based on preheating/precooling the cold/hot fresh outside air by means of the relatively hot/cold exhaust air in winter/summer weather conditions. To investigate the feasibility of such a concept, an experimental setup is established to simulate conditions similar to an All-Air HVAC system. The prototype consists of a $6.7-\mathrm{m}^{3}$ airconditioned chamber by means of a split unit of 5.3-kW capacity. The heat recovery module consists of a duct system that is used to reroute the exhaust air from a conditioned chamber to flow through the fin side of a fin-and-tube heat exchanger of crossflow type. At the same time, outside, fresh air is flowing through the tube side of the fin-and-tube heat exchanger. A parametric study is performed to assess the amount of heat that can be recovered by varying the mass flow rates on both the duct and heat exchanger sides. The results show that up to $200 \mathrm{~W}$ of power can be saved for an exhaust flow rate of $0.1 \mathrm{~kg} / \mathrm{s}$ and a fresh, outdoor air flow rate of $0.05 \mathrm{~kg} / \mathrm{s}$. Environmentally speaking, this leads to a reduction in production of about 1 tons of $\mathrm{CO}_{2}$ per year when the system operates $24 \mathrm{~h} /$ day. From an economic point of view, the system is able to return its price after 1.5 years when it is used $24 \mathrm{~h}$ per day during hot days at 196-W thermal recovery, whereas it requires at least 6.3 years when it is used during cold days at a $60-\mathrm{W}$ thermal recovery rate, which, in both cases, represents a duration less than the lifespan of an air conditioner.
\end{abstract}

Keywords: heating; cooling; exhaust air; heat exchanger; heat recovery; experimental setup

\section{Introduction}

The actual global shift in energy usage nowadays is towards a decrease in fuel consumption, thereby reducing harmful carbon dioxide emissions. This can be achieved by energy management and renewable energy [1-6]. In particular, heat recovery represents a key aspect in the notable growth of energy management efforts [7-11]. The vast range of applications of heat recovery includes ICEs-internal combustion engines [11], chimneys [12-16], energy recovery from shower water drain [17,18], and HVAC (Heating Ventilating and Air Conditioning) $[19,20]$. Heat recovery is based on the idea that waste heat generated by a process is used for either heating purposes or non-heating purposes. Waste heat appears in several applications, especially in manufacturing processes [21,22].

Moreover, heating, ventilating, and air conditioning systems (HVAC) are no longer a luxury but a necessity for citizens and thus require a variety of energy systems that need to be handled increasingly [23]. However, HVAC systems account for one-third of energy consumption for society. As a result, the aim to reduce the energy load of the HVAC 
system and consequently reduce the environmental impacts and costs has become a topic of interest for many researchers. Studies have mainly focused on controlling the flow of air using VAV (Variable Air Volume) or VRV (Variable Refrigerant Volume) methods in response to the variations of energy loads in demand, while other studies have focused on improving the efficiency of specific equipment such as coils or refrigerators in order to increase the efficiency of the overall system.

For example, Mancini et al. [24] evaluated the building energy requirements and the Indoor Environmental Quality while varying the mass flow rate of the HVAC system, which is provided by air-handling units. The results showed that a $50 \%$ reduction in the air flow rate will have a significant reduction of energy consumption of the building by up to $45 \%$, with a negligible impact on the IEQ. As a matter of fact, one of the important solutions to reduce energy requirements is to have efficient control of the HVAC system flow rates, especially during low-occupancy periods.

Nevertheless, cooling outside fresh air represents $20-40 \%$ of the total energy consumption for HVAC in hot weather conditions, for example, and the percentage can even attain higher values if the demand for fresh air increases in critical situations, such as in hospitals, kitchens, or factories. Heat recovery from air exhaust to fresh air is considered a crucial step towards reducing the energy needs of a building. The common methods are mainly divided into two categories: energy wheels and static heat exchangers.

Examining the literature, it is noticed that studies that deal with heat recuperation in all-air HVAC setups are scarce. Moreover, studies on the recovery of heat from HVAC systems' exhausted airflow (cold/hot) are mainly on a large scale, using thermal wheel or a fixed plate heat exchanger. In this context, the present study concerns cooling/heating fresh inlet airflow using the exhaust cold/hot airflow from HVAC setups. The idea, for example, for a conditioned room in a cold climate is to heat or preheat the fresh outside air by utilizing the drained hot air from the room.

All-water, all-air, and water-air are the three basic configurations of HVAC technologies. All-water-type distributes heat or cool water for the conditioned space using pipes, while, in water-air systems, water and air are both utilized to heat or cool a certain space, whereas the all-air type has gained this terminology in HVAC because the regulation of humidity and temperature is done by air supply only. Figure 1 illustrates the working principle for this HVAC system type [23].

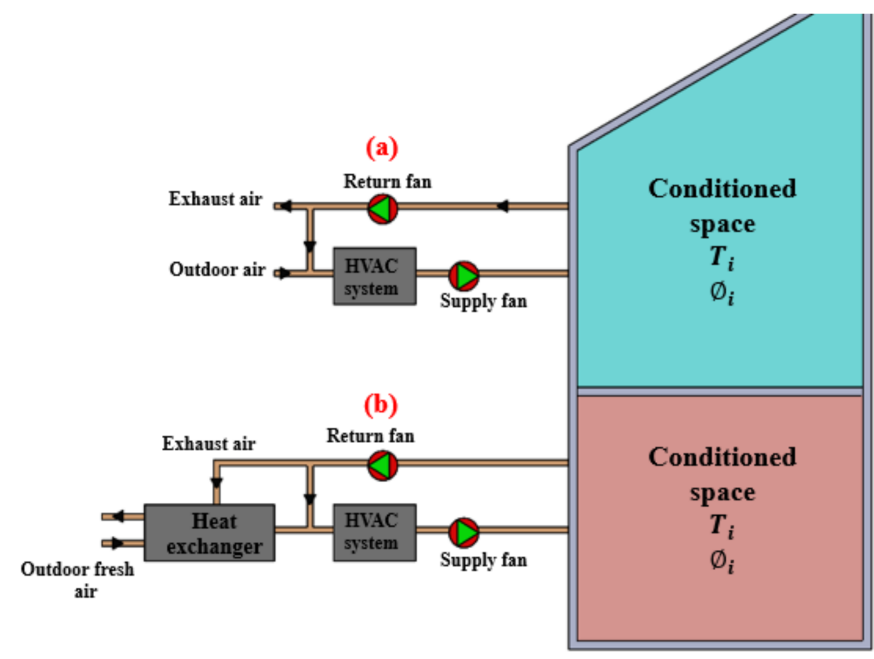

Figure 1. (a) All-air HVAC system illustration, and (b) schematic of the HVAC system with heat recovery.

The configuration of different parts is presented in Figure 1a. The "Air Handling Unit" (AHU) is intended to add or take away energy from airstreams prior to their supply to air-conditioned spaces [23]. In fact, it enables air to be heated, cooled, humidified, dehumid- 
ified, cleaned, and circulated to different air-conditioned areas in the zone. Additionally, outside air is introduced and inside air is extracted by means of the AHU. Thus, to balance between efficiency and comfort, a portion of the return air outside of the air-conditioned area is drained, and then, an equivalent quantity of outdoor air is combined. This permits a constant supply of fresh air to the space and mitigates the energy requirements for the let-in air to be totally conditioned from the outside air.

Ramadan et al. [25] performed a parametric study on HVAC systems with air-water heat recovery. A counter-flow concentric tube heat exchanger at the condenser is used. Heated air downstream the condenser warms up the tube water. The results showed that the outlet temperature of the water rises from $31^{\circ} \mathrm{C}$ to $74{ }^{\circ} \mathrm{C}$ for an increase of the cooling load from 3.52 to $63.31 \mathrm{~kW}$. Yau et al. [25] performed a heat recovery study using a heat pipe heat exchanger (HPHE) from an all-air HVAC setup. HPHE with two, four, six, and eight rows were tested. The coil face velocity was $2 \mathrm{~m} / \mathrm{s}$, while the temperature of the return air was $24{ }^{\circ} \mathrm{C}$. HPHE results were recorded over one week. It showed an overall yearly savings of $2885 \mathrm{kWh}$, which can be raised to $7023 \mathrm{kWh}$ per year if an eight-row HPHE is used. In addition, the volumetric flow rate will be increased, and a higher amount of energy recovery is expected as the face velocity is increased, but this results in a higher-pressure drop in the coil, which decreases the effectiveness. Shen et al. [26] investigated a fixed-plate heat recovery setup for a liquid desiccant regenerator. Process prediction, testing, and discussion with heat recovery was facilitated by a simple heat and mass transfer model for the fixed plate. The predicted results and the investigated values were compared. The experimental results confirmed the predicted values with an error rate lower than $11 \%$ for all performances. Additionally, $16-19 \%$ of the total consumption of energy was recovered from the outlet air, which led to about 14-18\% savings of energy. Nasif et al. [27] studied how an air conditioning system is affected when equipped with an air-to-air fixed plate heat exchanger for energy recovery. Multiple counter-flow configurations were investigated, namely, L-shaped, Z-shaped, and Z-shaped opposite flows. The experimental results showed that the L-shaped heat exchanger provided energy savings up to 20,833 $\mathrm{kWh}$ in comparison to the two other layouts. Moreover, the recovery of the L-shaped exchanger was up to $25,000 \mathrm{kWh}$ more than the other configurations.

This paper suggests a heat recovery concept that is based on preheating/precooling the cold/hot fresh outside air by means of the relatively hot/cold exhaust air in cold weather conditions. It is attained at this time by a compact air-to-air crossflow heat exchanger (applicable on the scale of large and small buildings also); its two airflow streams are the outside and exhaust airflows, as shown in Figure $1 \mathrm{~b}$.

The remainder of this manuscript is ordered as the following: Section 2 provides the materials and methods, Section 3 exposes the results and analysis, Section 4 presents an economic and environmental study, and lastly, Section 5 exhibits the main conclusions.

\section{Materials and Methods}

For the investigation purposes discussed in the preceding section, an experimental implementation of the suggested heat recovery setup was made. The prototype consists mainly of a wood box that represents the conditioned space (room). This box has a volume of $6.7 \mathrm{~m}^{3}$, and its walls have a thickness of $15 \mathrm{~mm}$ and a thermal conductivity of $0.15 \mathrm{~W} / \mathrm{mK}$. Furthermore, an air-conditioning split system of $5.3 \mathrm{~kW}$-capacity is utilized to supply the cold and hot air to the chamber, and the heat recovery system is ensured by the ducting system. This ducting system is composed of a duct that is isolated (adiabatic), fin-and-tube heat exchanger of a crossflow type (air-to-air), and a variable speed fan. Figure 2 shows the schematics of this implemented prototype.

The air speed (and then flow rate) and temperature are measured at different locations for the purpose of testing the system's performance. The five temperatures in the duct downstream and upstream of the fin-and-tube heat exchanger, at the heat exchanger's inlet and outlet, and in the box are read continuously by using digital type $\mathrm{K}$ thermocouples. The air velocities at the two outlets of the heat exchanger are measured by using two 
anemometers. One of the two speeds is used to calculate the air flow rate through the heat exchanger (through the tubes); the second one is used to calculate the air flow rate passing the geometry of the heat exchanger (through the fins).

On the other hand, the outside cold and hot climates (outside airflow) are simulated using a compressor and a turbine fan, respectively.

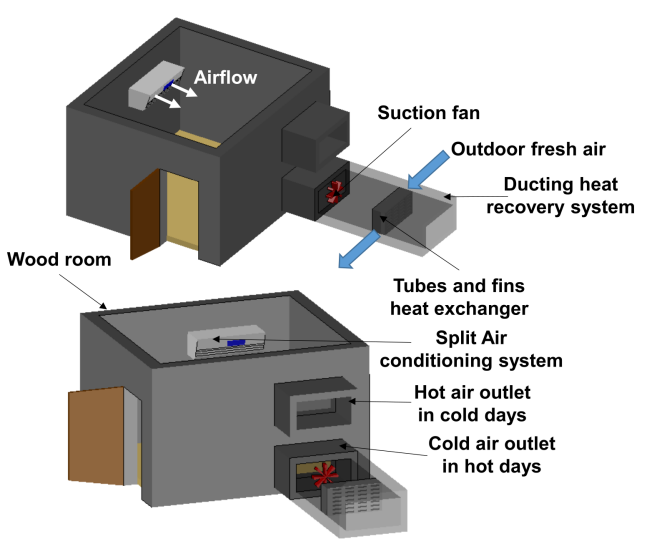

Figure 2. Schematic of the experimental prototype.

It should be noticed that the conditioned space is equipped with two openings (Figure 2): one at the bottom of the room for outdoor hot weather simulation conditions and another one for outdoor cold weather simulation conditions. These openings are used in each case to connect the heat recovery system to the conditioned space at the appropriate locations of the presence of hot and cold air for the return.

The air mass flow rates flowing in the exchanger $\dot{\mathrm{m}}_{\text {exchanger }}$ and through it $\dot{\mathrm{m}}_{\mathrm{duct}}$ are estimated as:

$$
\begin{aligned}
\dot{\mathrm{m}}_{\text {exchanger }} & =\rho_{\mathrm{a}} \mathrm{A}_{\text {out,exchanger }} \mathrm{V}_{\mathrm{av}, \text { out }} \\
\dot{\mathrm{m}}_{\text {duct }} & =\rho_{\mathrm{a}} \mathrm{A}_{\text {duct }} \mathrm{V}_{\mathrm{av}, \text { duct }}
\end{aligned}
$$

where $\rho_{\mathrm{a}}$ is the density of air, $\mathrm{A}_{\text {out,exchanger }}$ and $\mathrm{A}_{\text {duct }}$ are, respectively, the heat exchanger outlet cross-section area and the duct's cross-section area, where the heat exchanger is placed. $V_{a v, \text { out }}$ and $V_{a v}$,duct are the average velocities of air at the heat exchanger outlet and on a plane of the duct downstream the heat exchanger, respectively.

The heat gained or lost by the airflow in the heat exchanger and through it is estimated by using the equations below, respectively:

$$
\begin{aligned}
& \dot{\mathrm{Q}}_{\text {exchanger }}=\dot{\mathrm{m}}_{\text {exchanger }} \mathrm{C}_{\mathrm{p}, \mathrm{a}}\left|\mathrm{T}_{\mathrm{a} \text {,outlet }}-\mathrm{T}_{\mathrm{a} \text {,inlet }}\right| \\
& \dot{\mathrm{Q}}_{\text {duct }}=\dot{\mathrm{m}}_{\text {duct }} \mathrm{C}_{\mathrm{p}, \mathrm{a}}\left|\mathrm{T}_{\mathrm{a} \text {,downstream }}-\mathrm{T}_{\mathrm{a} \text {, upstream }}\right|
\end{aligned}
$$

where $C_{p, a}$ is the heat capacity of air, and $T_{a, \text { inlet }}$ and $T_{a \text {,outlet }}$ are the exchanger's inlet and outlet air temperatures, respectively. $T_{a, d o w n s t r e a m}$ is the air temperature downstream the exchanger, and $\mathrm{T}_{\mathrm{a} \text {,upstream }}$ is the air temperature upstream the exchanger.

Finally, the effectiveness " $\varepsilon$ " of the fin-and-tube exchanger is represented as a fraction of the real heat exchanged over the maximum possible heat exchange and estimated by the following equation:

$$
\varepsilon=\frac{\mathrm{m}_{\mathrm{h}, \mathrm{f}} \cdot C \mathrm{p}_{\mathrm{h}, \mathrm{f}}\left(\mathrm{T}_{\mathrm{h}, \mathrm{f} \text { out }}-\mathrm{T}_{\mathrm{h}, \mathrm{f} \text { in }}\right)}{\mathrm{m}_{\mathrm{h}, \mathrm{f}} \cdot C \mathrm{P}_{\mathrm{h}, \mathrm{f}}\left(\mathrm{T}_{\mathrm{h}, \mathrm{f} \text { in }}-\mathrm{T}_{\mathrm{c}, \mathrm{f} \text { in }}\right)}
$$

where $m_{h, f}, C p_{h, f}, T_{h, f}$ out, and $T_{h, f}$ in are, respectively, the mass flow rate, heat capacity, and hot fluid's outlet and inlet temperatures. $\mathrm{T}_{\mathrm{c}, \mathrm{f}}$ in is the cold fluid's inlet temperature.

Four tests are done, and the operating conditions, along with air properties, evaluated at the average temperature between the indoor and outdoor conditions are represented in Table 1. Two tests were performed in which the exchanger flow rate was variated and duct 
flow rate was maintained constant on cold and hot days (tests number 1 and 3), and then, the experiments were repeated, in which the exchanger flow rate was maintained constant and the duct flow rate was variated (tests number 2 and 4). It should be noted that the duct system is placed at the upper opening of the room on cold days, since the hot air has a low density and will concentrate in the upper part of the room, while, on hot days, the duct system is placed in the lower part, since the cold air of the room has a high density and will concentrate at the lower part of the room.

Moreover, in order to validate the experimental results, an uncertainty analysis is considered for the temperature measurements, since the heat transfer rates (recovered heats) depend mainly on the measurements of the temperatures. Variations of the air temperatures at the inlets and outlets of the cold and hot sides for the tests repeated twice under the same operating conditions and configuration and then for different operating conditions (three) are considered (which gives a total of six tests). It was found that the maximum mean temperature difference between the tests is about $0.4{ }^{\circ} \mathrm{C}, 1.8 \%$ relative difference, suggesting that the temperature variation is well-reproduced by repeating the same test and conserving the same operating conditions. On the other hand, the maximum error of positioning thermocouples in the air streams is $0.5^{\circ} \mathrm{C}$. Then, with an average measured temperature of $22^{\circ} \mathrm{C}$, the maximum relative error due to the present method of thermocouple positioning does not exceed $2.3 \%$.

Finally, with $1.8 \%$ repeatability and $2.3 \%$ precision error of the temperature measurements, the uncertainty gives $97.1 \%$ confidence in the temperature measurements.

Table 1. Tests conditions.

\begin{tabular}{|c|c|c|c|}
\hline Test Number & Exchanger Flow Rate & Duct Flow Rate & Conditions \\
\hline 1 & $\begin{array}{l}\text { Constant } \\
(0.044 \mathrm{~kg} / \mathrm{s})\end{array}$ & $\begin{array}{c}\text { Variable } \\
(0.05-0.2 \mathrm{~kg} / \mathrm{s})\end{array}$ & $\begin{array}{l}\text { For hot days simulations. } \\
\text { The exchanger and its associated duct system are placed at } \\
\text { the lower window of the room. }\end{array}$ \\
\hline 2 & $\begin{array}{c}\text { Variable } \\
(0.022-0.05 \mathrm{~kg} / \mathrm{s})\end{array}$ & $\begin{array}{c}\text { Constant } \\
(0.111 \mathrm{~kg} / \mathrm{s})\end{array}$ & $\begin{array}{ll}\text { - } & \text { Room temperature }=22{ }^{\circ} \mathrm{C} \\
\text { - } & \text { Outdoor temperature }=36^{\circ} \mathrm{C} \\
\text { - } & \text { Air density } \rho=1.17 \mathrm{~kg} / \mathrm{m}^{3} \\
\text { - } & \text { Specific heat } C_{\mathrm{p}}=1.006 \mathrm{~kJ} / \mathrm{kgK}\end{array}$ \\
\hline 3 & $\begin{array}{c}\text { Constant } \\
(0.022 \mathrm{~kg} / \mathrm{s})\end{array}$ & $\begin{array}{c}\text { Variable } \\
(0.05-0.2 \mathrm{~kg} / \mathrm{s})\end{array}$ & $\begin{array}{l}\text { For cold days simulations, ice is used to obtain low } \\
\text { temperatures of air at the exchanger inlet. } \\
\text { The exchanger and its associated duct system are placed at } \\
\text { the upper window of the room. }\end{array}$ \\
\hline 4 & $\begin{array}{c}\text { Variable } \\
(0.022-0.05 \mathrm{~kg} / \mathrm{s})\end{array}$ & $\begin{array}{l}\text { Constant } \\
(0.111 \mathrm{~kg} / \mathrm{s})\end{array}$ & $\begin{array}{ll}\text { - } & \text { Room temperature }=22{ }^{\circ} \mathrm{C} \\
\text { - } & \left.\left.\text { Outdoor temperature }=5{ }^{\circ} \mathrm{C} \text { (case } 3\right) \text { and } 9{ }^{\circ} \mathrm{C} \text { (case } 4\right) \\
\text { - } & \text { Specific heat } C_{p}=1.006 \mathrm{~kJ} / \mathrm{kgK}\end{array}$ \\
\hline
\end{tabular}

In the four experiments, for each couple of air speed at the exchanger outlet and downstream, four readings of the temperatures at the different locations are recorded to allow estimating the different heat rates and mass flow rates given by Equations (1)-(4). The results of the four experiments, as well as the corresponding discussions, are presented in the next section.

\section{Results and Discussion}

\subsection{Results for Hot Day Conditions}

Simulating the hot days is done by passing the turbine fan air into the heat exchanger; the first experimental set is performed with an inlet temperature of $36{ }^{\circ} \mathrm{C}$ to the exchanger and a fixed $\dot{\mathrm{m}}_{\text {exchanger }}=0.044 \mathrm{~kg} / \mathrm{s}$. A $22^{\circ} \mathrm{C}$ room temperature has been set. The cold air flow rate, which simulates the exhaust air in the duct, is changed within the range $0.05-0.2 \mathrm{~kg} / \mathrm{s}$. This case represents test number 1 . Figure 3 a represents the evolution of the 
heat exchanger's heat transfer rate lost by the hot air and gained by cold air with respect to the exhausted cold mass flow rate.

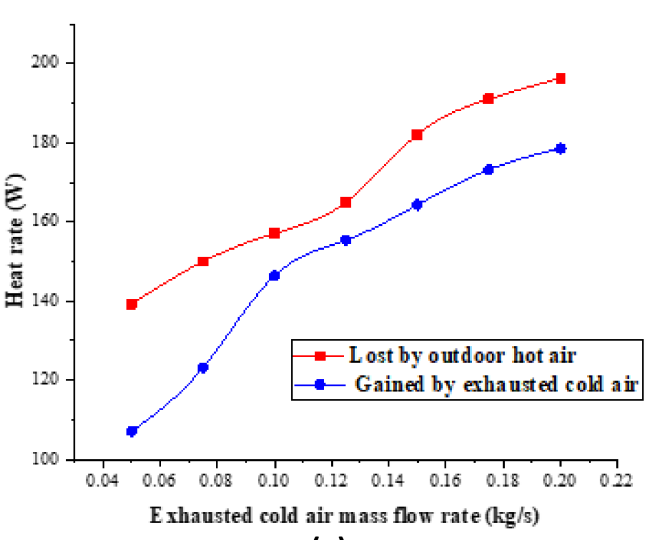

(a)

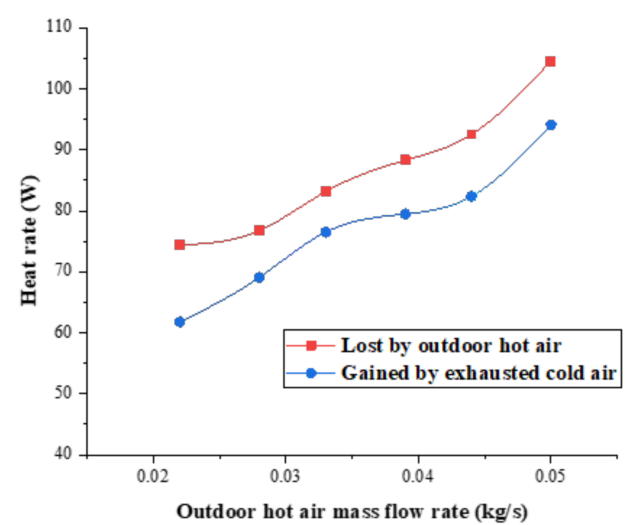

(b)

Figure 3. (a) Hot air lost heat rate and cold air gained heat rate in terms of the cold air flow rate (test 1), and (b) hot air lost heat rate and cold air gained heat rate in terms of the hot air flow rate (test 2).

As shown in Figure 3a, with the increase of the exhaust cold air flow rate in the duct, the two heat rates increase. The gained heat by airflow through the heat exchanger is smaller than the lost heat by airflow in the heat exchanger. To illustrate, the heat gain by air flowing through the heat exchanger, as well as the heat lost by airflow in the heat exchanger, increase from $107 \mathrm{~W}$ and $139 \mathrm{~W}$ to $179 \mathrm{~W}$ and $196 \mathrm{~W}$, respectively, when the exhaust cold air flow rate in the duct increases from 0.05 to $0.2 \mathrm{~kg} / \mathrm{s}$. This leads to an exchanger average effectiveness of $87 \%$, estimated using Equation (5).

To simulate the hot days also, a second experimental set was performed. In this case, the inlet temperature of the exchanger is set at $36{ }^{\circ} \mathrm{C}$, the cold air flow rate is fixed at $\dot{\mathrm{m}}_{\mathrm{duct}}=0.111 \frac{\mathrm{kg}}{\mathrm{s}}$, and the temperature of the room is also chosen as $22^{\circ} \mathrm{C}$. The outdoor hot air flow rate, which simulates the air in the heat exchanger, is increased from 0.022 to $0.05 \mathrm{~kg} / \mathrm{s}$. This case represents test number 2 . Figure $3 \mathrm{~b}$ represents the evolution of the heat exchanger's heat transfer rate lost by the exchanger's hot air and gained by the duct cold air with respect to the exchanger (hot) mass flow rate.

As shown in Figure 3b, the two heat rates increase when the exchanger's hot air mass flow rate increases. The gained heat by air flowing through the heat exchanger is smaller than the lost heat by air flowing through the heat exchanger. To illustrate, the heat gain by air flowing through, and the heat lost by air in, the heat exchanger increases from $62 \mathrm{~W}$ and $74 \mathrm{~W}$ to $94 \mathrm{~W}$ and $105 \mathrm{~W}$, respectively, when the exchanger's hot air mass flow rate increases from 0.022 to $0.05 \mathrm{~kg} / \mathrm{s}$. This leads to an exchanger average effectiveness of $89 \%$.

\subsection{Results for Cold Day Conditions}

To simulate cold days, an experimental set was first performed. In this case, the inlet exchanger temperature is set at $5^{\circ} \mathrm{C}$, the cold air flow rate in the exchanger is fixed at $\dot{\mathrm{m}}_{\text {exchanger }}=0.022 \frac{\mathrm{kg}}{\mathrm{s}}$, and the temperature of the room is also chosen as $22{ }^{\circ} \mathrm{C}$. The hot flow rate of air, which simulates the air in the duct, is changed between 0.05 and $0.2 \mathrm{~kg} / \mathrm{s}$. Figure 4 a represents the evolution of the heat transfer rate gained by the exchanger's cold air and lost by the duct hot air with respect to the duct (hot) air mass flow rate.

As shown in Figure 4a, the two heat rates (lost by the duct air and gained by the heat exchanger air) increase as the mass flow rate of the duct hot air increases. The gained heat by airflow in the heat exchanger is smaller than the heat lost by the airflow through it. To illustrate, the heat gain by air flowing in the heat exchanger and the heat lost by the airflow through the heat exchanger increase from $58 \mathrm{~W}$ and $72 \mathrm{~W}$ to $87 \mathrm{~W}$ and $99 \mathrm{~W}$, respectively, 
when the mass flow rate of the duct hot air increases from 0.05 to $0.2 \mathrm{~kg} / \mathrm{s}$. This leads to an exchanger average effectiveness of $87 \%$.

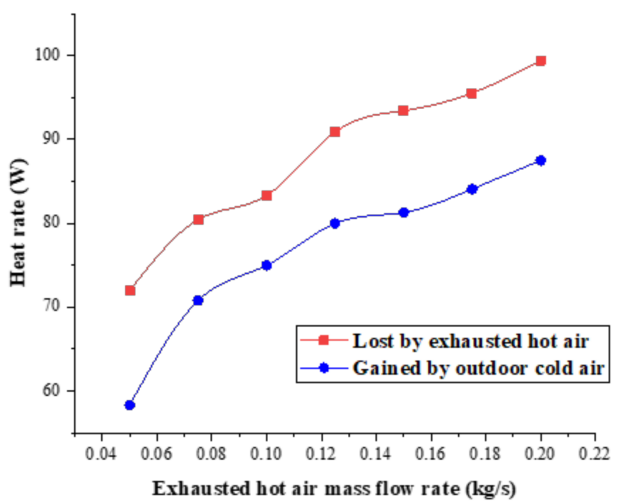

(a)

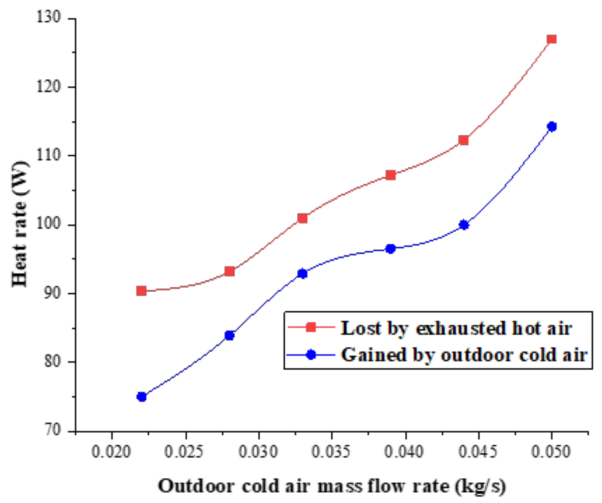

(b)

Figure 4. (a) Hot air lost heat rate and cold air gained heat rate in terms of the hot air flow rate (test 3), and (b) hot air lost heat rate and cold air gained heat rate in terms of the cold air flow rate (test 4).

To simulate cold days also, a second experimental set was performed. In this case, the inlet exchanger temperature is set at $9{ }^{\circ} \mathrm{C}$, the duct hot air flow rate is fixed at $\dot{\mathrm{m}}_{\text {duct }}=0.111 \frac{\mathrm{kg}}{\mathrm{s}}$, and the temperature of the room is also chosen as $22{ }^{\circ} \mathrm{C}$. The cold air flow rate, which simulates the exchanger's airflow, is changed from 0.022 to $0.05 \mathrm{~kg} / \mathrm{s}$. Figure $4 \mathrm{~b}$ represents the evolution of the heat transfer rate gained by the exchanger's cold air and lost by the duct hot air with respect to the (cold) air mass flow rate.

As shown in Figure $4 b$, the two heat rates (lost by duct air and gained by heat exchanger air) increase as the mass flow rate of the exchanger's cold air increases. The gained heat by airflow in the heat exchanger is smaller than the lost heat by airflow through it. To illustrate, the heat gain by air flowing in the heat exchanger and the heat lost by the airflow through the heat exchanger increase from $75 \mathrm{~W}$ and $90 \mathrm{~W}$ to $114 \mathrm{~W}$ and $127 \mathrm{~W}$, respectively, when the exchanger's cold air mass flow rate increases from 0.022 to $0.05 \mathrm{~kg} / \mathrm{s}$. This leads to an exchanger average effectiveness of $89 \%$.

By comparing cases 2 and 4 (has same flow rate conditions but different climate) with a $0.022-\mathrm{kg} / \mathrm{s}$ outdoor flow rate, approximately same amount of heat was recovered in both cases (about $75 \mathrm{~W}$ ). Increasing this flow rate to $0.05 \mathrm{~kg} / \mathrm{s}$, the heat recovery on cold days is higher compared to hot days (about $10 \mathrm{~W}$ more). This means, in such scenarios, the system is more efficient on cold days.

Additionally, it is concluded that part of the thermal energy that the hot fluid loses is not gained by the cold fluid, which mainly results from the effectiveness of the heat exchanger. That said, it was noticed that, with the increase of the outdoor air mass flow rate, the exchanger's effectiveness is larger compared to when the mass flow rate of the indoor air is increased in both hot and cold cases.

\section{Economic and Environmental Study}

The suggested heat recovery setup for all-air HVAC systems was evaluated economically and environmentally for different conditions to estimate the money savings, payback period, and carbon dioxide $\left(\mathrm{CO}_{2}\right)$ reduction quantity.

In order to perform a comprehensive simplified study, the minimum and maximum amount of heat recovered are considered in the study, i.e., $60 \mathrm{~W}$ and $196 \mathrm{~W}$, respectively. Then, the study considered the intermediate levels of performance when the system recovered $105 \mathrm{~W}$ and $140 \mathrm{~W}$ from the exhausted air.

To proceed, the amount of heat energy recovered per month by this setup $E_{h}$ is calculated with the equation below:

$$
\mathrm{E}_{\mathrm{h}}=\mathrm{Q}_{\mathrm{rec}} \times \mathrm{N}_{\mathrm{hr}} \times \mathrm{N}_{\mathrm{d}}
$$


where $Q_{\text {rec }}$ is the heat recovered, and $N_{h r}$ and $N_{d}$ are, respectively, the number of running hours per day and number of days per month. As the system can run for different numbers of hours, the study will be a function of this parameter.

Eventually, the amount of electric energy $\mathrm{E}_{\mathrm{E}}$ saved per month is estimated by considering a 75\% energy conversion efficiency [27] of the air conditioner $(\eta)$ and is represented in Figure 5a:

$$
\mathrm{E}_{\mathrm{E}}=\frac{\mathrm{E}_{\mathrm{h}}}{\eta}
$$

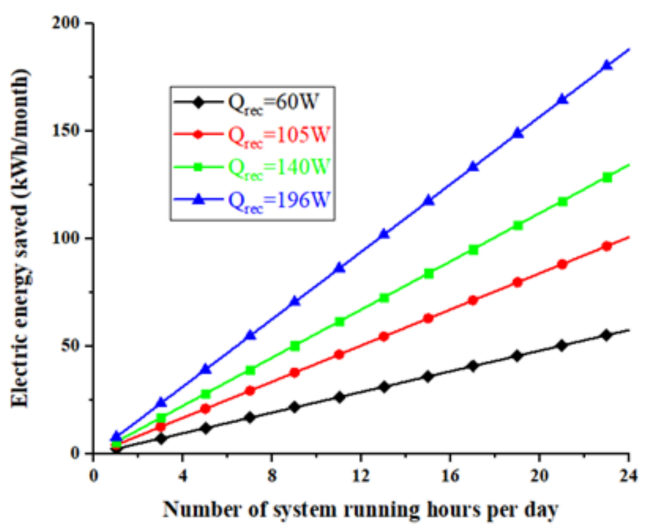

(a)

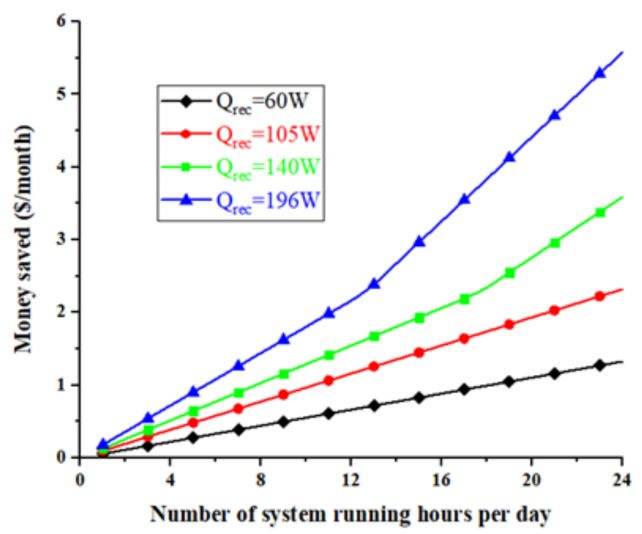

(b)

Figure 5. (a) Amount of electric energy saved by the system for different running hours, and (b) amount of money economized by utilizing the recovery system.

Figure 5a shows that the electric energy saved ranges between $2.4 \mathrm{kWh}$ and $190 \mathrm{kWh}$ per month on the basis of the amount of recovered energy and the system running time (hours). On hot days, and when the system is capable of recovering $196 \mathrm{~W}$, the electric energy saved raises from $8 \mathrm{kWh}$ to $190 \mathrm{kWh}$ when the system runs 2 and $24 \mathrm{~h}$, respectively, while it increases from $2.4 \mathrm{kWh}$ to $58 \mathrm{kWh}$ when the system is able to recover $60 \mathrm{~W}$ (on cold days). This means that the system is more cost-effective on hot days compared to cold days and capable of economizing more electric energy, which will directly affect the amount of saved money, payback period, and amount of carbon dioxide gases reduced.

Additionally, the amount of money saved monthly $\mathrm{mS}$ is determined by Equation (7) and shown in Figure 5b.

$$
\mathrm{MS}=\mathrm{E}_{\mathrm{E}} \times \mathrm{C}
$$

where $C$ is the cost per kilowatt/hour. The cost per kilowatt/hour in Lebanon is subjected to progressive tax [22] and can be estimated based on Equation (8).

$$
\left\{\begin{array}{c}
\text { if } \mathrm{E}_{\mathrm{E}} \leq 99[\mathrm{kWh}] \\
\rightarrow \mathrm{C}=0.023 \times \mathrm{E}_{\mathrm{E}}[\$] \\
\text { if } 99<\mathrm{E}_{\mathrm{E}} \leq 299[\mathrm{kWh}] \\
\rightarrow \mathrm{C}=0.023 \times 99+0.037 \times\left(\mathrm{E}_{\mathrm{E}}-99\right)[\$]
\end{array}\right\}
$$

Figure $5 \mathrm{~b}$ shows that the system is able to economize about $6 \$$ /month on hot days at full run and about $2 \$ /$ month on cold days (approximately at $\mathrm{Q}_{\mathrm{rec}}=105 \mathrm{~W}$ ). It should be noted that the system runs at a low air mass flow rate, and as it increases, the money saved increases. This means that, if the system is allowed to run at a higher flow rate, more money is expected to be saved.

To evaluate the recovery system's payback period, the overall system cost must be estimated. The system is composed of a heat exchanger, duct, and pipes, with a total cost of $\$ 100$, including the installation cost and welding. 
Based on previous comments, the payback period PBP equation is as follows:

$$
\mathrm{PBP}=\frac{\text { Cost of system }}{\mathrm{MS}}
$$

Figure 6a shows the payback period. It shows that the duration of the payback is highly affected by the number of system running hours. It highly descends as a function of the number of hours. The system is able to pay for itself after 1.5 years when it is used $24 \mathrm{~h}$ per day on hot days at 196-W thermal recovery, whereas it requires at least 6.3 years when it is used on cold days at a $60-\mathrm{W}$ thermal recovery rate. It should be noticed that, if the system is utilized for about $8 \mathrm{~h}$ per day, the payback period of the system will be less than 6 years if $196 \mathrm{~W}$ is recovered by the system. This duration is less than the lifespan of an air conditioner.

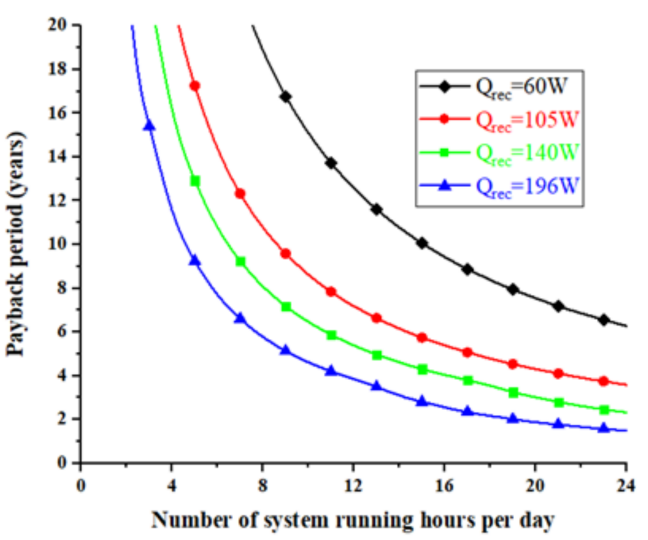

(a)

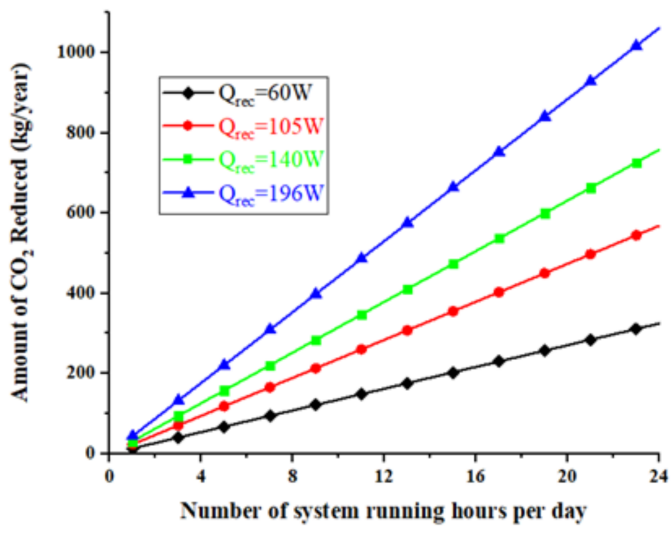

(b)

Figure 6. (a) Heat recovery system's payback period in years, and (b) amount of $\mathrm{CO}_{2}$ gas reduced yearly.

Lastly, as for the environmental concern, the quantity of $\mathrm{CO}_{2}$ gas reduced $\mathrm{m}_{\mathrm{CO} 2}$ is calculated using Equation (10) and represented in Figure 6b.

$$
\mathrm{M}_{\mathrm{CO}_{2}}=\mathrm{E}_{\mathrm{E}} \times \mathrm{Mg}_{\mathrm{g}}
$$

where $\mathrm{m}_{\mathrm{g}}$ is the quantity of carbon dioxide produced for one kilowatt/hour of electricity generated. Based on Lebanese studies, the amount of $\mathrm{CO}_{2}$ generated is $0.47 \mathrm{~kg} / \mathrm{kWh}$ [16].

The system can reduce up to 1 ton of carbon dioxide emissions yearly when the system recovers $196 \mathrm{~W}$, which decreases to a 300-kg maximum when it recovers $60 \mathrm{~W}$. However, it should be noted that, in fact, the system reduces more emissions, since this study is based on the electric energy of air conditioners while more electric energy should be generated at an electric power plant to cover the losses through the grid lines.

Since hot/cold air is allowed to move at a low flow rate, the money saved, payback period and $\mathrm{CO}_{2}$ quantity reduced are relatively low. However, those results show a very promising system when run at higher flow rates, allowing for greater energy recovery.

\section{Conclusions}

This paper presents the theory, design, experimental implementation and parametric study of a system for cooling/precooling or heating/preheating fresh, incoming air by utilizing relatively cold or hot air exhausted from all-air HVAC setups. A heat recovery finsand-tubes air-to-air heat exchanger experiment was carried out, and a parametric analysis was conducted to determine the effect of the flow rate on the system's performance. The experiments were carried out under hot and cold climate conditions using a 5.3-kW AC unit. The results showed that the heat recovery device's efficiency indicated improvements with both the exhaust and outdoor air flow rates. It was also shown that up to around 
$110 \mathrm{~W}$ and $200 \mathrm{~W}$ of power can be saved for an exchanger air mass flow rate of $0.05 \mathrm{~kg} / \mathrm{s}$ and a duct air mass flow rate of $0.1 \mathrm{~kg} / \mathrm{s}$ in cold and hot conditions, respectively.

Author Contributions: Conceptualization, M.K.; Data curation, S.A. and H.J.; Formal analysis, M.K., S.A., H.J., J.F., R.M. and T.L.; Investigation, M.K., S.A., H.J., J.F., R.M. and T.L.; Methodology, M.K., S.A. and H.J.; Project administration, M.K.; Supervision, M.K.; Validation, S.A. and H.J.; Writing—original draft, M.K., S.A. and H.J.; Writing-review \& editing, J.F., R.M. and T.L. All authors have read and agreed to the published version of the manuscript.

Funding: The APC was funded by the Lebanese International University.

Institutional Review Board Statement: Not applicable.

Informed Consent Statement: Not applicable.

Data Availability Statement: Not applicable.

Conflicts of Interest: The authors declare no conflict of interest.

\section{Nomenclature}

$\begin{array}{ll}\text { A } & \text { Area }\left(\mathrm{m}^{2}\right) \\ C_{p} & \text { Specific heat at constant pressure }(\mathrm{kJ} / \mathrm{kg} \cdot \mathrm{K}) \\ \mathrm{E} & \text { Energy }(\mathrm{kJ}) \\ \dot{\mathrm{m}} & \text { Air mass flow rate }(\mathrm{kg} / \mathrm{s}) \\ \mathrm{M} & \text { Mass }(\mathrm{kg}) \\ \dot{Q} & \text { Heat transfer rate }(\mathrm{kW}) \\ \mathrm{T} & \text { Temperature }\left({ }^{\circ} \mathrm{C}\right) \\ \mathrm{V} & \text { Air velocity }(\mathrm{m} / \mathrm{s}) \\ \text { Greek } & \\ \mathcal{\varepsilon} & \text { Effectiveness } \\ \rho & \text { Density }\left(\mathrm{kg} / \mathrm{m}^{3}\right) \\ \eta & \text { Energy conversion efficiency } \\ \text { Subscripts } & \\ \mathrm{a} & \text { Air } \\ \text { av } & \text { Average } \\ \mathrm{c}, \mathrm{f} & \text { Cold fluid } \\ \mathrm{d} & \text { Days } \\ \mathrm{E} & \text { Electric } \\ \mathrm{h}, \mathrm{f} & \text { Hot fluid } \\ \mathrm{h} & \text { Recovered } \\ \text { hr } & \text { Hours } \\ \text { Acronym } & \\ \mathrm{MS} & \text { Amount of money saved in US dollars } \\ \text { PBP } & \text { Payback period in years }\end{array}$

\section{References}

1. Abualigah, L.; Abu Zitar, R.; Almotairi, K.H.; Hussein, A.M.; Elaziz, M.A.; Nikoo, M.R.; Gandomi, A.H. Wind, Solar, and Photovoltaic Renewable Energy Systems with and without Energy Storage Optimization: A Survey of Advanced Machine Learning and Deep Learning Techniques. Energies 2022, 15, 578. [CrossRef]

2. Akhatova, A.; Kranzl, L.; Schipfer, F.; Heendeniya, C.B. Agent-Based Modelling of Urban District Energy System DecarbonisationA Systematic Literature Review. Energies 2022, 15, 554. [CrossRef]

3. Arraño-Vargas, F.; Shen, Z.; Jiang, S.; Fletcher, J.; Konstantinou, G. Challenges and Mitigation Measures in Power Systems with High Share of Renewables-The Australian Experience. Energies 2022, 15, 429. [CrossRef]

4. Thummar, K.; Abang, R.; Menzel, K.; de Groot, M.T. Coupling a Chlor-Alkali Membrane Electrolyzer Cell to a Wind Energy Source: Dynamic Modeling and Simulations. Energies 2022, 15, 606. [CrossRef]

5. Herez, A.; Ramadan, M.; Khaled, M. Review on solar cooker systems: Economic and environmental study for different Lebanese scenarios. Renew. Sustain. Energy Rev. 2018, 81, 421-432. [CrossRef]

6. Jaber, H.; Khaled, M.; Lemenand, T.; Faraj, J.; Bazzi, H.; Ramadan, M. Effect of Exhaust Gases Temperature on the Performance of a Hybrid Heat Recovery System. Energy Proc. 2017, 119, 775-782. [CrossRef] 
7. Jaber, H.; Khaled, M.; Lemenand, T.; Ramadan, M. Effect of generator load on hybrid heat recovery system. Case Stud. Therm. Eng. 2019, 13, 100359. [CrossRef]

8. Xu, Z.; Wang, R.; Yang, C. Perspectives for low-temperature waste heat recovery. Energy 2019, 176, 1037-1043. [CrossRef]

9. Christodoulides, P.; Agathokleous, R.; Aresti, L.; Kalogirou, S.A.; Tassou, S.A.; Florides, G.A. Waste Heat Recovery Technologies Revisited with Emphasis on New Solutions, Including Heat Pipes, and Case Studies. Energies 2022, 15, 384. [CrossRef]

10. Wang, F.; Wang, L.; Ou, Y.; Lei, X.; Yuan, J.; Liu, X.; Zhu, Y. Thermodynamic analysis of solid oxide electrolyzer integration with engine waste heat recovery for hydrogen production. Case Stud. Therm. Eng. 2021, 27, 101240. [CrossRef]

11. Danieli, P.; Masi, M.; Lazzaretto, A.; Carraro, G.; Volpato, G. A Smart Energy Recovery System to Avoid Preheating in Gas Grid Pressure Reduction Stations. Energies 2022, 15, 371. [CrossRef]

12. Salimzadeh, S.; Grandahl, M.; Medetbekova, M.; Nick, H.M. A novel radial jet drilling stimulation technique for enhancing heat recovery from fractured geothermal reservoirs. Renew. Energy 2019, 139, 395-409. [CrossRef]

13. Khaled, M.; Ramadan, M.; El Hage, H. Parametric Analysis of Heat Recovery from Exhaust Gases of Generators. Energy Procedia 2015, 75, 3295-3300. [CrossRef]

14. Khaled, M.; Ramadan, M. Study of the thermal behavior of multi concentric tube tank in heat recovery from chimney-Analysis and optimization. Heat Transf. Eng. J. 2017, 8, 399-409.

15. Khaled, M.; Ramadan, M.; Chahine, K.; Assi, A. Prototype implementation and experimental analysis of water heating using recovered waste heat of chimneys. Case Stud. Therm. Eng. 2015, 5, 127-133. [CrossRef]

16. Jaber, H.; Khaled, M.; Lemenand, T.; Murr, R.; Faraj, J.; Ramadan, M. Domestic thermoelectric cogeneration drying system: Thermal modeling and case study. Energy 2019, 170, 1036-1050. [CrossRef]

17. Jaber, H.; Ramadan, M.; Lemenand, T.; Khaled, M. Domestic thermoelectric cogeneration system optimization analysis, energy consumption and CO2 emissions reduction. Appl. Therm. Eng. 2018, 130, 279-295. [CrossRef]

18. Pochwat, K.; Kordana, S.; Starzec, M.; Słyś, D. Comparison of two-prototype near-horizontal Drain Water Heat Recovery units on the basis of effectiveness. Energy 2019, 173, 1196-1207. [CrossRef]

19. Ramadan, M.; Lemenand, T.; Khaled, M. Recovering heat from hot drain water-Experimental evaluation, parametric analysis and new calculation procedure. Energy Build. 2016, 128, 575-582. [CrossRef]

20. Salameh, W.; Castelain, C.; Faraj, J.; Murr, R.; El Hage, H.; Khaled, M. Improving the efficiency of photovoltaic panels using air exhausted from HVAC systems: Thermal modelling and parametric analysis. Case Stud. Therm. Eng. 2021, 25, 100940. [CrossRef]

21. Kanaan, M. CFD optimization of return air ratio and use of upper room UVGI in combined HVAC and heat recovery system. Case Stud. Therm. Eng. 2019, 15, 100535. [CrossRef]

22. O'Connor, D.; Calautit, J.K.; Hughes, B.R. A review of heat recovery technology for passive ventilation applications. Renew. Sustain. Energy Rev. 2016, 54, 1481-1493. [CrossRef]

23. McQuiston, F.; Parker, J.D.; Spitler, J.D. Heating, Ventilating and Air Conditioning: Analysis and Design, 6th ed.; John Wiley \& Sons: New York, NY, USA, 2005.

24. Mancini, F.; Nardecchia, F.; Groppi, D.; Ruperto, F.; Romeo, C. Indoor Environmental Quality Analysis for Optimizing Energy Consumptions Varying Air Ventilation Rates. Sustainability 2020, 12, 482. [CrossRef]

25. Ramadan, M.; El Rab, M.G.; Khaled, M. Parametric analysis of air-water heat recovery concept applied to HVAC systems: Effect of mass flow rates. Case Stud. Therm. Eng. 2015, 6, 61-68. [CrossRef]

26. Shen, S.; Cai, W.; Wang, X.; Wu, Q.; Yon, H. Investigation of liquid desiccant regenerator with fixed-plate heat recovery system. Energy 2017, 137, 172-182. [CrossRef]

27. Nasif, M.S.; Al-Waked, R. Effect of Air to Air Fixed Plate Enthalpy Energy Recovery Heat Exchanger Flow Profile on Air Conditioning System Energy Recovery. Appl. Mech. Mater. 2016, 819, 245-249. [CrossRef] 